\title{
Determining the Underlying Dimensions of Quality of Work Life (QWL) in the Nigerian Hotel Industry
}

\author{
Nguwasen Kwahar, Akuraun Shadrach lyortsuun
}

\begin{abstract}
A B S T R A C T
Objective: The objective of this paper is to explore the underlying dimensions of quality of work life (QWL) in the Nigerian hotel industry.

Research Design \& Methods: With a defined population of 3.110, a sample size of 355 was determined using probability technique, which formed the participants of the study. Employing the Delphi technique, eight experts and four cycles of inputs led to a consensual number of sixty-three indicators of QWL which formed the final inventory or variables of the quality of work life dimensions used for exploratory factor analysis. Exploratory factor analysis with varimax rotation was employed. Kaiser criterion, examination of the scree plot and Horn parallel analysis (Horn, 1965) guided factor extraction.
\end{abstract}

Findings: Preliminary assessment conducted confirmed the appropriateness of the dataset for factor analysis. Furthermore, based on the extraction criteria, five factors were extracted which explained $59.37 \%$ of the total variance in QWL in the Nigerian hotel industry, labelled as remuneration and benefits, job security and career satisfaction, training and opportunities for personal autonomy, home-work balance and safe and healthy environment.

Implications \& Recommendations: The Nigerian hotel industry should focus on the QWL factors which the study reports as most considered by employees. The study has also identified the dimensions of QWL in the Nigerian hotel industry.

Contribution \& Value Added: This study identifies the latent variables that show QWL in the Nigerian hotel industry, which are labelled as remuneration and benefits, job security and career satisfaction, training and personal autonomy, home-life balance and safe and healthy environment. The managerial implication is that owners and operators of hotels in Nigeria can benefit by understanding what quality of work life entails and which indicators show the concept.

\section{Article type: research paper}

Keywords: quality of work life; latent variables of QWL; exploratory factor analysis; underlying dimensions of QWL; Nigerian hotel industry

JEL codes: M54, L83

Received: 21 June 2017 Revised: 30 August 2017 Accepted: 9 February 2018

\section{Suggested citation:}

Kwahar, N., \& lyortsuun, A.S. (2018). Determining the Underlying Dimensions of Quality of Work Life (QWL) in the Nigerian Hotel Industry. Entrepreneurial Business and Economics Review, 6(1), 53-70. https://doi.org/10.15678/EBER.2018.060103 


\section{INTRODUCTION}

The 21st century has posed grave challenges to human resource management in organisations with the human factor recognized as the most important organisational resource which defines the prosperity and survival of organisations (Sojka, 2014; Kwahar, 2016). It therefore behoves on organisations to manage this important resource effectively and efficiently if they are to be successful in the contemporary and competitive environment. This becomes more important given the proliferation of technology at the work place (Hunker, 2014). Technology has become fundamental for and inseparable from organisations, especially in the contemporary business environment with the success of businesses dependent on its acceptability and scalability in the work place (Shengbin \& Yo, 2011). Technology has also influenced human resource policies leading to creative solutions to attract and retain the best and productive workforce (Gardner, Lepak, \& Bartol, 2003; Selvan, 2015). The focus of such innovative human resource policies is on maintaining high quality of work life with the hope of improving employee satisfaction and ultimately organisational performance. This scenario is aggressively being pursued in the hotel industry in Nigeria.

As clearly highlighted, central to the success of an organisation is the human resource, and fundamental to the productivity of the human resource is its quality of work life. Quality of work life as a complex and multidimensional concept addresses issues relating to conditions of work and the organisation's work environment and how it impactson employee's satisfaction, work life, non-work life and overall life (Psychogio, 2005; Naude, Kruger, \& Saayman, 2015). Places, things, activities, people, social roles or elements of self-concept define an employee's life with the dynamism between employees and work environment in a formal organisation defined as quality of work life (Sojka, 2014; Naude et al., 2015). The hotel industry espouses quality of work life as the humanisation of the work environment by focusing on task, physical work environment, social relationships, remuneration and reward system, management systems and employee relationship off and on the job. Therefore, quality of work life as a behavioural concept focuses on an individual's perception of and attitudes towards his or her work and the total working environment (David, Brazil, Krueger, Lohfield, \& Tjam, 2001; Pulakos, 2009; Nickson, 2009).

A dearth of empirical research on the latent variables explaining quality of work life in the Nigerian hotel industry is what this study hopes to address. On the one hand, Nigerian researchers have focused mostly on explaining the literature and theories of quality of work life and on the other hand, employing predefined quality of work life constructs to assess its impact on organisational performance. There is a minimal attempt to explore the underlying constructs or the latent variables defining quality of work life, especially as regards the hotel industry in Nigeria. This identified research gap is what this study hopes to achieve.

Therefore, this research focuses on delineating the underlying dimensions of quality of work life by performing a principal components analysis on the identified indicators of quality of work life in the Nigerian hotel industry. The scope of the study is limited to fivestars hotels in Nigeria. Compared to hotel industries in other countries, the Nigerian hotel industry is relatively nascent (Kwahar, 2016). The Nigeria National Institute for Hospitality and Tourism [NIHT] (2015) classifies five hotels as five-stars in Nigeria. The justification of selecting only the five-stars hotels is based on the fact that they are top of the range in terms of the provision of hotel services and is regarded as ensuring a relatively high degree 
of provision of quality of work life (NIHT, 2015). Furthermore, the five-stars hotels are a good representation of hotels in Nigeria as lower-ranked hotels understudy their programmes, policies and strategies. Indeed, the research findings would also be applicable to lower-ranked hotels in the Nigerian hotel industry.

The paper is therefore divided into the following sub-sections: introduction, literature review, material and measures, results and discussion and lastly conclusion.

\section{LITERATURE REVIEW}

Elton Mayo and F. J. Roethlisberger's argument for a humanistic approach to management changed the focus from productivity and targets. This approach gave birth to the human relations movement targeted at employer-employee relations and remuneration programmes in the work environment (Levitt \& List, 2011). The psychological contract theory (March \& Simon, 1993; Rousseau, 1995; Coyle-Shapiro \& Parzefall, 2008) and the social exchange theory (Homans, 1961; Blau, 1964; Emerson, 1976, 1987; Cook \& Rice, 2003) among others have attempted to explain the dynamism between employees and their work environment. These theoretical foundations have provided the impetus for researchers to delineate latent variables to show quality of work life.

Almarshad's (2015) study in Saudi Arabia identified seventy-nine items as measures of quality of work life but when the items were subjected to factor analysis, thirty items loaded on a four-factor structure. Stress at work, preoccupation with work, job and career satisfaction and working conditions were the underlying constructs of quality of work life identified in their research. On their part, Levine, Taylor and Davis (1984), using a six-stage Delphi technique, identified a seven-structure quality of work life construct defined using thirty-four items as a degree to which my superiors treat me with respect and have confidence in me, variety in my daily work routine, challenge of my work, my present work leads to good future work opportunities, self-esteem, extent to which my life outside of work affects my life at work and lastly, the extent to which the work I do contributes to society.

Wyatt and Wah (2001) research on what constitutes quality of work life in Singapore also arrived at a thirty-five, four-structure underlying dimension of what constitutes quality of work life, delineated as supportive management and favourable work environment, personal growth and autonomy, nature of the job and stimulating opportunities and coworkers. In another study, Rethinam and Ismail (2008) modelled quality of work life among information and technology professionals in Malaysia. They identified a five-structure dimension of quality of work life, which they defined as health and well-being, job security, job satisfaction, competency development and work and non-work life balance.

Sojka (2014) researching in the Slovak economic environment classified the indicators of quality of work life into three broad classes as primary, secondary and tertiary characteristics. These classes were therefore broken down into a ten-structure dimension of quality of work life listed as financial reward, work load, content of work, social relations, work position and possibility for further development, working conditions, enterprise localisation, benefits, corporate culture and enterprise image. For Hunker (2014), his study on the underlying constructs of quality of work life focused on contingent workers in the Danish hospitality industry. Hunker identified an eightstructure quality of work life dimension, which he listed as credibility, pride in work 
and company, respect, camaraderie and friendliness, openness and fairness, job security, pay and benefits and opportunities.

Van Laar, Edwards and Easton (2007) comprehensive research on quality of work life in the United Kingdom health sector resulted in twenty-three items and a six-structure model of work-related quality of life, which they propose as possible to be applied in the health care sector. They conceptualised quality of work life as job and career satisfaction, general well-being, home-work interface, stress at work, control at work and working conditions. On the other hand, Walton's (1974) quality of work life model delineated an eight-structure dimension as adequate and fair remuneration, safe and healthy environment, development of human capacities, growth and security, social integration, constitutionalism, total life space and social relevance.

Worthy of mention is the study by Swamy, Nanjundeswaraswamy and Rashmi (2015) on the indicators of quality of work life in India. Their study produced a 27 -item questionnaire and a nine-structure construct as the quality of work life which they named work environment, organisation culture and climate, relation and co-operation, training and development, remuneration and rewards, facilities, job satisfaction and job security, autonomy of work and adequacy of resources. Hossain's (2013) study focusing on the garment industry in Bangladesh was based on an 85-item instrument as indicators of quality of work life. His factor analytic result revealed five latent variables of quality of work life as nature of the job and career progress, relationship with the supervisor, favourable work environment, rewards and recognition and union-management relations. Lastly, a study conducted by Das and Gope (2013) in the Indian manufacturing sector, specifically in the sugar mills sub-sector involving both the cooperative and private sugar mills, revealed a ten factor-structure as measures of quality of work life, which was defined as comfortable work space, lighting facilities, level of temperature, health facilities, safety measures, physical working conditions, employee welfare facilities, standard of welfare facilities, supervisor interference and lastly job stress.

Different indicators or dimensions are used to show quality of work life. The broad categories of what constitutes quality of work life from the review could be conveniently grouped into indicators that show employees' satisfaction with the work they do; indicators that show how employees are treated or regarded at their work place; indicators that show how the work impacts on employees' life outside work; indicators that show employees' working conditions; indicators that show the opportunities and challenges available at the work place; indicators that show a safe work environment and lastly indicators that show the impact the job has on the physiology, emotion and psychology of employees. Each grouping identifies different elements of what constitutes quality of work.

Therefore, what constitutes quality of work life is dependent on the environment and the industry where the study is undertaken. Going by the review, the quality of work life dimension is dependent on the economic and social-cultural factors existing in the locality where the study was conducted. Furthermore, the industry where the study took place also contributes. Indeed, both an organisation's internal and external environment contributes to explaining the nature and substance of what constitutes quality of work life. Therefore, a static view of quality of work life would be counterproductive; hence, the need to empirically determine what constitutes quality of work life. It is based on the following argument that this study hopes to determine the latent variables or underlying dimensions of quality of work life in the Nigerian hotel industry. Exploratory factor analysis is used to achieve this objective. 


\section{MATERIAL AND METHODS}

\section{Participants}

The scope of this study is influenced by the nature and infancy of the hotel industry in Nigeria when compared to other climes. The study is therefore limited to only five-stars hotels in Nigeria because they define the standard in hotel management in Nigeria. They are indeed the cynosure of the Nigerian hotel industry and therefore models for lower - ranked hotels in the country. The scope is therefore representative of the hotel industry in Nigeria as findings can be readily generalised to other lower-ranked hotels in $\mathrm{Ni}$ geria. According to Kwahar (2016), the five top five-stars hotels in Nigeria are Transcorp Hilton, Abuja, Sheraton Hotel, Abuja, Eko Hotel and Suites, Lagos, International Hotel, Lagos and Hotel Presidential, Port-Harcourt with a total of 3.110 employees. Using the Taro Yamane (1967) formula, a sample of 355 was determined, which formed the participants of the study. Bowley's (1964) proportional allocation formula was adopted in distributing the sample to the hotels selected. However, only 327 individuals from the five five-stars hotels finally agreed to participate in the research, an acceptable figure for principal components analysis (Tabachnik \& Fidell, 2007; Yong \& Pearce, 2013). To deal with sampling error and bias, probability technique was implemented.

\section{Measures}

Levine et al. (1984) argues that what constitutes quality of work life is best defined by those to which the concept applies and are knowledgeable in it. This study supports this argument, reinforcing the use of the Delphi technique in gaining insight into what constitutes quality of work life or the indicators of quality of work life in the Nigerian hotel industry. Knowledgeability, expertise, consensus, iteration, anonymity and statistical aggregation of opinions among others are the hallmarks of the Delphi criteria (Hsu \& Sandford, 2007; Skulmoski, Hartman, \& Krahn, 2007). However, there is generally no acceptable criterion for the selection of subjects and determination of the number of experts in a Delphi panel (Delbecq, Van de Ven, \& Gustafson, 1975) with decision influenced by time, expense and quality of the expert panel (Hassan, Keeney, \& McKenna, 2000; Thangaratinam \& Redman, 2005) and indeed, the area of the study. The recommendation by Linstone (1978) for a minimum of seven members influenced the decision to employ eight experts, four each from the Nigerian university system and top-level managers working in the hotel industry in Nigeria. Given the unique characteristics of the Nigerian hotel industry, the group started with one hundred and twenty-eight indicators of quality of work life. Four cycles of inputs, suggestions and consensus amongst the group members led to a consensual number of sixty-three indicators (Appendix A), which formed the final inventory or variables of the quality of work life dimensions used for exploratory factor analysis. The variables consisted of six negatively worded questions which were reversed before conducting the exploratory factor analysis. Seventeen weeks was the duration within which the four Delphi cycles were concluded.

The 63 variables were presented using a five-point Likert scale with five representing 'strongly agree', four indicating 'agree', three indicating 'undecided', two indicating 'disagree' and lastly one indicating 'strongly disagree'. A total number of 355 questionnaires were therefore distributed to the employees of the selected hotels. Five research assistants as- 
sisted in the distribution and collection of the questionnaires administered to the hotels under study. To ensure that the questionnaires distributed were returned, adequate time was allowed. From the administration to the return of the questionnaires, a total of twenty-three weeks were allowed. The sufficiently allowed time increased the number of questionnaires filled and returned that were used for the exploratory factor analysis.

\section{Data Analysis}

The main objective of this study is to explore the underlying dimensions of quality of work life in the Nigerian hotel industry. Based on this objective, exploratory factor analytic technique is the most appropriate tool to achieve this objective. Using SPSS v.20, principal component analysis was employed in exploring the correlations of the observed variables of quality of work life. As argued by Tabachnik and Fidell (2007), principal component analysis focuses on extracting the maximum variance from the observed variables. It is a technique that produces the latent variables by summarising the correlation among the observed variables under study. Orthogonal rotation, specifically varimax rotation, was employed as the rotation technique. The choice of varimax and therefore principal components analysis was based on the fact that no significant difference was observed between the result of principal axis factoring with oblimin rotation and principal component analysis with orthogonal rotation. Principal component with varimax rotation was therefore preferred given the simplistic nature of explaining the extracted components in line with the stated objectives of this study. Furthermore, the number of factors retained was guided by three criteria: Kaiser criterion with eigenvalues greater than one, examination of the scree plot and Horn parallel analysis (Horn, 1965), which is the most preferred technique in the decision for factor retention (Tabachnik \& Fidell, 2007; Matsunaga, 2010; Hair, Babin, \& Anderson, 2010). In parallel analysis, factors are retained that have eigenvalues more than eigenvalues from a randomly generated dataset with a similar sample size and number of variables. This was the criterion that determined the retention of factors in this study with the minimum threshold for rotated components specified as 0.50 (Hair et al., 2010) to help achieve simple structure (Thurstone, 1947).

\section{RESULTS AND DISCUSSION}

\section{Preliminary Analysis}

Preliminary assessment was conducted to ensure the appropriateness of using exploratory factor analysis with the dataset. The correlation matrix did not show patterned relationships among the observed variables. To confirm this further, the Haitovsky (1969) test indicated that the determinant score was significantly different from zero, indicating the absence of multicollinearity. Also, a spot check of the observed variables linearity (Tabachnik \& Fidell, 2007) shows the absence of a curvilinear relationship between the variables. The spot check also led to the identification of seventeen outlying cases which were removed, leading to a reduced number of 315 cases that were used for further analysis. Further test conducted included the KMO and Bartlett's Test of Sphericity. The Bartlett's Test of Sphericity (Bartlett, 1954) is statistically significant with $\chi^{2}(1770)=$ $12,837.79, p<0.001$, indicating the factorability of the correlation matrix, while the Kaiser-Meyer-Olkin Measure of Sampling Adequacy was 0.856 exceeding the recom- 
mended value of 0.6 (Kaiser, 1970, 1974). Also, the diagonal elements of the Anti-Correlation matrix were all above the recommended value of 0.5 (Hair et al., 2010; Yong \& Pearce, 2013) indicating that reliable and distinct factors can be produced.

An initial analysis of the data resulted in the extraction of thirteen factors with eigenvalues above one and five items not loading on any factor. Different techniques were employed to determine the appropriate extraction and rotation technique with the goal of achieving simple structure (Thurstone, 1947). To achieve this objective, the removal of items was based on the following criteria: (a) when items do not load on a factor (b) when items are highly correlated amongst themselves to affect the factorability of the correlation matrix (c) when items have low communality with the factors. Based on these criteria, a total number of twenty-nine items were therefore removed. Also, oblimin rotation did not show a significantly high correlation between the extracted factors with the correlation ranging from -0.021 to highest of -0.307 . Indeed, only factor 1 and 2 had a correlation coefficient above 0.3 , that is -0.307 otherwise, all of the correlation coefficients of the extracted factors were less than 0.3. This reinforced the choice of Varimax as the factor rotation technique of choice.

\section{Exploratory Assessment of Measures}

The objective of the study was achieved using principal components analysis with varimax rotation. Five factors or components were extracted following the guidelines determined in this study. Six factors showed eigenvalues above one. However, the scree plot suggested the extraction of five factors, which was confirmed by the result of Horn's parallel analysis. The result of the parallel analysis showed eigenvalues exceeding the corresponding criterion values for a randomly generated data matrix of the same size (34 items $\times 315$ respondents). The result of the five-factor structure of quality of work life in the Nigerian hotel industry is presented as Table 1.

The five factors explained $59.37 \%$ of the total variance in the quality of work life in the Nigerian hotel industry, which is slightly below the recommended minimum of $60 \%$ as suggested by Hair et al. (2010). However, Peterson (2000, p. 263) argues that there is no 'generalisation regarding an acceptable threshold' for the minimum total variance explained. Tinsley and Tinsley (1987, p. 420) argue that 'an analysis in which factors explain only 30$40 \%$ of the estimated common variance obviously leaves an alarming amount of common variance unexplained' and claimed that a factor solution should account for at least $50 \%$ of the total variance explained (Tinsley \& Tinsley, 1987; Merenda, 1997). This is supported by the research conclusion by Peterson $(2000$, p. 268 ) in his meta-analytical study, which shows that on average, ' $56.6 \%$ of the variance in the respective set of variables' factor analysed is reported by factor analytic studies. These research conclusions justified the acceptance of the reported total variance explained of $59.37 \%$.

Factor 1 labelled as 'remuneration and benefits' contributes in 18.52\%, factor 2 labelled as 'job security and career satisfaction' contributes in 15.84\%, factor 3 labelled as 'training and opportunities for personal autonomy' contributes in $8.99 \%$, factor 4 labelled as 'home-work balance' contributes in $8.24 \%$ and lastly, factor 5 labelled as 'safe and healthy environment' contributes in $7.80 \%$. The total explained variance is reasonable within the acceptable threshold and therefore regarded adequate in explaining the variance in quality of work life in the Nigerian hotel industry. According to Stevens (2002), factor loadings above 0.4 are considered adequate, hence, the 
choice of 0.50 (Hair et al., 2010) to achieve simple structure. Therefore, items with loadings of less than 0.5 were omitted for clarity with only 'no minimal control at work by supervisor when target achieved' being the only item with cross loading on factor 3 and 4 with a load of 0.50 on factor 3 and -0.55 on factor 4 .

Communalities measure the proportion of each item variance accounted by the extracted factors or latent variables and as (Table 1 ) shows, the communalities range from 0.48 to 0.70 , which satisfies the acceptable threshold suggested by Field (2009). Also, the calculated Cronbach's Alpha $(\propto)$ for the latent variables or the extracted factors shows that 'remuneration and benefits' has a value of 0.91 , 'job security and career satisfaction' 0.89 , 'training and opportunities for personal autonomy' 0.73 , 'home-work balance' 0.73 and 'safe and healthy environment' 0.71 . All the alpha values are above the minimum threshold value of 0.70 for the early stage research as suggested by Nunnally (1978).

The result of the exploratory factor analysis indicates that five constructs account for the variance of the quality of work life of the hotel industry in Nigeria which are defined as 'remuneration and benefits', 'job security and career satisfaction', 'training and opportunities for personal autonomy', 'home-work balance' and 'safe and healthy environment'. These are the factors that define quality of work life in the Nigerian hotel industry. They are the underlying constructs that can be used as the benchmark measure of quality of work life in the hotel industry in Nigeria.

Table 1. Factor loadings, communalities (h2) and percent of variance for principal factors extraction with Varimax rotationa on the QWL items

\begin{tabular}{|l|c|c|c|c|c|c|}
\hline \multirow{2}{*}{\multicolumn{1}{|c|}{ Items }} & \multicolumn{3}{|c|}{ Component } & \multirow{2}{*}{$\mathbf{h}^{\mathbf{2}}$} \\
\cline { 2 - 6 } & $\mathbf{b}_{\mathbf{1}}$ & $\mathbf{F}_{\mathbf{2}}$ & $\mathbf{F}_{\mathbf{3}}$ & $\mathbf{F}_{\mathbf{4}}$ & $\mathbf{F}_{5}$ & \\
\hline Adequate remunertion & $\mathbf{0 . 7 4}$ & 0.16 & -0.17 & -0.01 & 0.11 & 0.62 \\
\hline Timely payment of salaries and allowances & $\mathbf{0 . 7 2}$ & 0.28 & 0.09 & 0.14 & 0.02 & 0.62 \\
\hline $\begin{array}{l}\text { Continuous review of pay based on response to change in cost } \\
\text { of living }\end{array}$ & $\mathbf{0 . 6 8}$ & 0.15 & -0.06 & 0.44 & 0.07 & 0.69 \\
\hline Performance based remuneration & $\mathbf{0 . 6 7}$ & 0.12 & 0.02 & 0.24 & 0.14 & 0.55 \\
\hline Fair and unbiased promotion system & $\mathbf{0 . 6 7}$ & 0.21 & 0.39 & 0.05 & 0.08 & 0.65 \\
\hline Fair remuneration & $\mathbf{0 . 6 7}$ & 0.18 & 0.30 & -0.03 & 0.06 & 0.56 \\
\hline Rewards for good work & $\mathbf{0 . 6 5}$ & 0.11 & 0.30 & 0.12 & -0.07 & 0.55 \\
\hline Adequate and comprehensive grade and pay structures & $\mathbf{0 . 6 5}$ & 0.47 & 0.14 & 0.02 & -0.19 & 0.70 \\
\hline $\begin{array}{l}\text { Appropriately implemented allowances and benefits (location } \\
\text { allowance, overtime and shift payments) }\end{array}$ & $\mathbf{0 . 6 3}$ & -0.04 & -0.22 & 0.04 & 0.25 & 0.51 \\
\hline Adequate employee benefits & $\mathbf{0 . 6 2}$ & 0.35 & 0.05 & -0.04 & -0.18 & 0.54 \\
\hline Fair financial incentive plan & $\mathbf{0 . 5 9}$ & 0.11 & 0.23 & 0.12 & 0.23 & 0.47 \\
\hline Above-average industry median salary & $\mathbf{0 . 5 8}$ & 0.16 & 0.36 & -0.15 & -0.04 & 0.52 \\
\hline Reward management procedures and policies & $\mathbf{0 . 5 8}$ & 0.14 & 0.05 & -0.36 & 0.27 & 0.56 \\
\hline Stability of employment & 0.04 & $\mathbf{0 . 7 9}$ & 0.16 & 0.12 & 0.02 & 0.67 \\
\hline Satisfaction with present job & 0.19 & $\mathbf{0 . 7 7}$ & -0.03 & -0.05 & 0.08 & 0.64 \\
\hline Work position and prospects of career development & 0.23 & $\mathbf{0 . 7 6}$ & 0.16 & 0.04 & 0.06 & 0.66 \\
\hline $\begin{array}{l}\text { Strict lay-off policies and faithfulness in implementing dismis- } \\
\text { sal policies }\end{array}$ & 0.21 & $\mathbf{0 . 7 5}$ & -0.01 & -0.07 & 0.08 & 0.62 \\
\hline $\begin{array}{l}\text { Supportive management and stimulating job and career op- } \\
\text { portunities }\end{array}$ & 0.24 & $\mathbf{0 . 7 0}$ & 0.01 & -0.08 & 0.07 & 0.57 \\
\hline
\end{tabular}




\begin{tabular}{|c|c|c|c|c|c|c|}
\hline \multirow{2}{*}{ Items } & \multicolumn{5}{|c|}{ Component } & \multirow{2}{*}{$h^{2}$} \\
\hline & ${ }^{\mathrm{b}} \mathbf{F}_{1}$ & $\mathbf{F}_{2}$ & $\mathbf{F}_{3}$ & $\mathbf{F}_{4}$ & $\mathbf{F}_{5}$ & \\
\hline Pride in work/company & 0.16 & 0.70 & 0.16 & 0.15 & 0.17 & 0.60 \\
\hline Satisfaction with career opportunities & 0.30 & 0.64 & 0.18 & 0.14 & -0.28 & 0.63 \\
\hline Attractiveness of present career & 0.05 & 0.62 & 0.16 & 0.37 & 0.11 & 0.56 \\
\hline Opportunity for management and operational decision making & 0.06 & 0.10 & 0.72 & 0.09 & 0.20 & 0.58 \\
\hline $\begin{array}{l}\text { Frequency and sufficiency of relevant and targeted training } \\
\text { programmes }\end{array}$ & 0.05 & 0.32 & 0.69 & 0.08 & -0.06 & 0.59 \\
\hline Training programmes aimed at improving interpersonal etc. skills & 0.27 & -0.15 & 0.69 & -0.04 & 0.17 & 0.60 \\
\hline $\begin{array}{l}\text { Training programmes focusing on employee requirements to } \\
\text { ensure promotion within }\end{array}$ & 0.00 & 0.42 & 0.62 & 0.02 & -0.15 & 0.58 \\
\hline Suitability of work hours/patterns to suit personal preference & 0.26 & 0.12 & 0.10 & 0.75 & 0.13 & 0.67 \\
\hline Opportunities for time off work with family and friends & 0.18 & 0.31 & -0.07 & 0.66 & 0.04 & 0.56 \\
\hline Non-availability of home-life balance programmes & 0.34 & -0.05 & 0.08 & -0.64 & 0.40 & 0.69 \\
\hline Flexibility in performing work responsibilities & 0.21 & -0.11 & 0.32 & 0.63 & 0.11 & 0.57 \\
\hline $\begin{array}{l}\text { No minimal control at work by supervisor when target } \\
\text { achieved }\end{array}$ & 0.21 & 0.14 & 0.51 & -0.55 & -0.08 & 0.63 \\
\hline Salubrious & 0.01 & 0.14 & -0.08 & -0.03 & 0.72 & 0.55 \\
\hline $\begin{array}{l}\text { Continuous risk assessment and safety inspections in the Or- } \\
\text { ganisation }\end{array}$ & 0.05 & 0.07 & 0.15 & 0.13 & 0.70 & 0.54 \\
\hline Updated work environment & 0.09 & -0.12 & -0.02 & -0.01 & 0.68 & 0.48 \\
\hline Safety measures/policies at work & 0.26 & 0.34 & 0.20 & 0.07 & 0.66 & 0.67 \\
\hline Eigenvalues & 9.63 & 3.28 & 2.71 & 2.34 & 2.24 & \\
\hline$\%$ of Variance & $\begin{array}{r}18.5 \\
2 \\
\end{array}$ & $\begin{array}{r}15.8 \\
4\end{array}$ & 8.99 & 8.24 & 7.80 & \\
\hline Cronbach alpha $(\propto)$ & 0.91 & 0.89 & 0.73 & 0.73 & 0.71 & \\
\hline \multicolumn{7}{|c|}{\begin{tabular}{|l} 
Extraction Method: Principal Component Analysis. \\
Rotation Method: Varimax with Kaiser Normalization. Rotation converged in six iterations.
\end{tabular}} \\
\hline $\begin{array}{l}\text { b. Factor Labels: } F_{1}=\text { Remuneration and Benefits; } F_{2}=\text { Job Se } \\
F_{3}=\text { Training and Opportunities for Personal Autonomy; } F_{4}= \\
F_{5}=\text { Safe and Healthy Work Environment }\end{array}$ & -1 & $\mathrm{dC}$ & 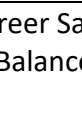 & atisf & & \\
\hline
\end{tabular}

Note: factor loadings over 0.50 appear in bold.

Source: own calculations based on the result of the exploratory factor analysis (2016).

\section{Factor 1: Remuneration and benefits}

'Remuneration and benefits' encompasses fair, adequate and timely financial and nonfinancial entitlements employees working in the hotel industry in Nigeria receive. Indeed, it implies an effective remuneration and reward management system, that is employee-centred, which aims to promote employee satisfaction and productivity. Remuneration and benefits is the most important factor of quality of work life in the Nigerian hotel industry, accounting for $18.5 \%$ of the variance in the quality of work life items. This implies that employees place high premium on remuneration, allowances and benefits as an important element of their work satisfaction and indeed non-work satisfaction. They expect employers or organisations to ensure a fair, adequate and comprehensive system of pay and reward. This holds true for employees working in the hotel industry in Nigeria (Nwadukwe, 2012; Kwahar, 2016). It is on the basis of this that remuneration and benefits comes top as the most important dimension of quality of work 
life in the Nigerian hotel industry. Also its Cronbach's Alpha $(\propto)$ of 0.91 is above the minimum threshold as suggested by Nunnally (1978).

Earlier research studies carried out by Walton (1974), Levine (1983), Wyatt and Wah (2001), Hossain (2013), Hunker (2014), Sojka (2014) and Swamy et al. (2015) have also identified remuneration and benefits as an indicator or a dimension of quality of work life. This has therefore supported the hypothesis that employees in the Nigerian hotel industry also acknowledge remuneration and benefits as being relevant and necessary if hotels in Nigeria hope to achieve quality of work. Expatiating further, based on the factor loadings of the items under remuneration and benefits, adequate remuneration ranks highest as the issue of choice for employees in the Nigerian hotel industry. Indeed, remunerating employees adequately would provide the impetus for organisational success (Namasivayam et al., 2007; Agba, 2007; Inyang \& Akpama, 2012; Imafidon, 2013; Armstrong, 2014). Other issues besides adequate remuneration in the order of ranking include timely payment of salaries and allowance, continuous review of pay based on response to the movement in the cost of living in the country, remuneration related to employee performance, fair and unbiased employee promotion system, fair remuneration to employees, rewarding employees for good work, adequate and comprehensive grade and pay system, appropriately implemented employee allowances and benefits, adequate benefits for employees, fair financial incentive plan, payment of above-average industry median salary and lastly implementing reward management procedures and policies. All of these issues define remuneration and benefit as a dimension of quality of work life in the Nigerian hotel industry.

\section{Factor 2: Job security and career satisfaction}

The second most important quality of work life dimension is 'job security and career satisfaction' as indicated by the total variance explained of $15.8 \%$. Its Cronbach's Alpha $(\propto)$ of 0.89 is also above the minimum threshold, (Nunnally, 1978). Research studies by Reithinam and Ismail (2008), Easton and Van Larr (2013), Hunker (2014), Sojka (2014), Gauri (2015) and Swamy et al. (2015) also identified aspects of job security and career satisfaction as the dimension of quality of work life. Job security involves policies which assure employees that they are an important resource in the organisation in such a way as to guarantee them sustainable employment for the organisation and not being expected to be sacked or removed unexpectedly and arbitrarily. When such a culture exist, employees working in such an organisation are reasonably expected to be satisfied working in such an organisation. Career satisfaction involves satisfaction with the work, which influences overall life satisfaction (Iverson \& Maguire, 2000; Diener, 2010; Thompson \& Phua, 2012). This might have justified the identification of job security and career satisfaction as a dimension of quality of work life in the Nigerian hotel industry. This is especially true given the proliferation of contingent work in the Nigerian hotel industry. Furthermore, the negative impact of the present economic recession may have influenced the respondents to consider job security and career satisfaction as a dimension of quality of work life in the Nigerian hotel industry.

In the order of importance, the issues covering job security and career satisfaction are stability of employment, satisfaction with present job, work position and prospects of career development, strict-layoff policies and faithfulness in implementing dismissal policies, supportive management and stimulating job and career opportunities, pride in work/company, satisfaction with career opportunities and attractiveness of present career. Based 
on the result, employees in the hotel industry in Nigeria believe that their quality of work life is improved when condition of service guarantees stability, which produces feelings of satisfaction with their job giving them opportunity to advance in their chosen career. On the other hand, when there are strict policies of layoffs, which are adherently followed, then this guarantees job security especially when the management is very supportive by giving opportunities to the employees. Furthermore, employees pride in the organisation contributes to the attractiveness of a career in the hotel industry in Nigeria. These are the issues regarding job security and career satisfaction in the Nigerian hotel industry.

\section{Factor 3: Training and opportunities for personal autonomy}

The result of the factor analysis shows that training and opportunities for personal autonomy ranks as the third most important dimension of quality of work life in the Nigerian hotel industry. The construct, which has a Cronbach's Alpha $(\propto)$ of 0.73 , accounts for a total variance explained of $10 \%$. This factor separately or together was also identified by earlier research conducted by Walton (1974), Levine (1983), Wyatt and Wah (2001), Mohamad and Mohamed (2012), Adetoyin (2012), Easton and Van Laar (2013), Hunker (2014), Sojka (2014), Gauri (2015) and Swamy et al. (2015) as a dimension of quality of work life.

Employee training is fundamental to organisational success. Training boostsan employee's chances to be relevant and gives them opportunities to contribute to organisational success. Creatively designed training programmes increase an employee's worth as an important resource with the attendant increase in responsibility and authority, thereby guaranteeing personal autonomy in the discharge of assigned duties. Hackman and Oldham $(1976,1980)$ define autonomy as the leverage to be independent, free and the discretion in performing a job. It is what employees working in the Nigerian hotel industry consider as the third most important dimension of quality of work life.

Five items make up the 'training and opportunities for personal autonomy' construct of the quality of work life. The fifth item cross-loads with the factor four, labelled as work-home balance. A review of the fifth item shows that it could indeed be considered an item of the 'training and opportunities for personal autonomy' quality of work life dimension. The fifth item is 'no minimal control at work by supervisor when target achieved' which could be regarded as an item under 'training and opportunities for personal autonomy' construct. Opportunity for management and operational decisionmaking accorded to employees is the item with the highest loading on the training and personal autonomy quality of work life dimension. It means that when employees are given an opportunity to participate in management and operational decisions based on the training received, then quality of work life is assured. The next item after opportunity for management and operation decision-making is frequency and sufficiency of relevant and targeted training programmes followed by training programmes aimed at improving interpersonal and other skills and training programmes focusing on employee requirements to ensure promotion within. The last item, which also loads on the work-home balance, is no minimal control at work by supervisor when target is achieved. This last item has the least loading on the training and personal autonomy dimension. These five items form the 'training and opportunities for personal autonomy' dimension of the quality of work life in the Nigerian hotel industry. 


\section{Factor 4: Home-work balance}

Organisations the world over including organisations in Nigeria, face the challenge of managing the conflict between employees work and their personal and family life. Organisations require employees to contribute their time, talent, knowledge and skills to ensure its success while employees on their part, desire to have time for their personal activities and with their family. These desires are in opposition to each other, requiring a delicate balancing act. The extent to which these conflicting issues are addressed effectively and efficiently, to that extent employees are encouraged to be active participants in the success story of such an organisation. 'Home-work balance' therefore implies employer-employee consensual decisions and policies that guarantee leverage to employees to attend to their non-work activities but also guarantee active participation of employees to the programmes and successes of the organisation. It is what Clark (2000) considers an equilibrium state with home and work duties that ensure satisfaction and good functioning. Home-work balance with a Cronbach's Alpha $(\propto)$ of 0.73 accounts for $8.2 \%$ of the variance in the quality of work life items making it the fourth most important dimension.

Five items load on the home-work dimension and as indicated by their factor loadings, suitability of work hours/patterns to suit personal preferences rates higher followed by opportunities for time off work with family and friends, non-availability of home-life balance programmes, flexibility in performing work responsibilities and nominimal control at work by supervisor when target achieved. As explained in the last section, 'no minimal control at work by supervisor when target achieved' loads on the third factor too but the loading on the home-work dimension is higher that it's loading on the training and autonomy dimension, hence its inclusion also on the home-work construct. However, the Cronbach's Alpha $(\propto)$ improves from 0.72 to 0.73 when 'no minimal control at work by supervisor when target achieved' is deleted, hence the decision not to include it as an item of the home-work dimension. Therefore, only the first four items as shown in (Table 1) are regarded as the sub-dimensions of the home-work construct of the quality of work life in the Nigerian hotel industry. Home-work construct as quality of work life dimension has also be reported by research conducted by Levine (1983), Reithinam and Ismail (2008), Easton and Van Laar (2013), Mohamad and Mohamed (2012), Sojka (2014), Gauri (2015) and Swamy et al. (2015), among others.

\section{Factor 5: Safe and healthy environment}

Based on the result of the analysis, 'safe and healthy environment' is the least important dimension of quality of work life in the hotel industry in Nigeria. The scope of the study may have influenced the result giving that it is only five-stars hotels in Nigeria that were considered. Being such a class of hotel, great effort is already taken by them to provide a safe and healthy environment. The construct only accounts for $7.8 \%$ of the variance in the quality of work life items with a Cronbach's Alpha $(\propto)$ of 0.71 . Safe and healthy environment defines the extent and ability of an organisation to provide a safe and healthy environment for employees, which invariably impacts positively on employee performance (Inyang \& Akpama, 2012; Nwadukwe, 2012).

Four items make up 'safe and healthy environment' as a construct of quality of work life in the Nigerian hotel industry. Looking at the factor loadings, a salubrious work environment 
is the most important item followed by continuous risk assessment and safety inspections in the work place. The third most important item under safe and healthy environment is an updated work environment and followed lastly by safety measures/policies at work at the organisation. These four issues taken together define 'safe and healthy environment' as a dimension of quality of work life in the hotel industry in Nigeria. Walton (1974), Mirvis and Lawler (1984), Van Laar et al., (2007), Easton and Van Laar (2013), Hossain (2013), Sojka (2014) and Swamy (2015) also support this view, reinforcing the conclusion that a safe and healthy work environment guarantees the existence of quality of work in hotels in Nigeria.

\section{CONCLUSIONS}

The objective of this study is to explore the underlying constructs or dimensions of quality of work life in the Nigerian hotel industry. To appreciate and achieve this objective, five-stars hotels operating in the Nigerian hotel industry defined the scope. Principal components analysis with Varimax rotation revealed the presence of five underlying constructs of quality of work life in the Nigerian hotel industry, which were labelled as 'remuneration and benefits', 'job security and career satisfaction', 'training and opportunities for personal autonomy', 'home-work balance' and 'safe and healthy environment'. These are the five factors that have formed the benchmark measures of quality of work life in the Nigerian hotel industry.

The major theoretical contribution of this research is in identifying the latent variables that show quality of work life in the Nigerian hotel industry, which are labelled as remuneration and benefits, job security and career satisfaction, training and personal autonomy, home-life balance and safe and healthy environment. The most significant managerial implication is that owners and operators of hotels in Nigeria can benefit by understanding what quality of work life entails and which indicators show the concept. Furthermore, operators and management of Nigerian hotels should focus on those factors that the study has reported as being the most valued quality of work life dimension as this would greatly influence the perceptual consideration by employees of the existence of quality of work life. Also, researchers, academics and students can now use the identified dimensions to test hypotheses regarding quality of work of life in the Nigerian hotel industry.

The major limitation of the study is that the scope is limited to five-stars hotels, neglecting lower-ranked hotels in Nigeria. Also, the study relied on the responses of the employees from the selected hotels under study, which may be affected by perceptual biases in answering the questionnaire. Furthermore, generalisation of the research findings to other countries would be limited, given that different countries adopt different criteria for hotel classification. Future research could be carried out to include lower-ranked hotels to delineate the factors which show quality of work life in the Nigerian hotel industry. Also, a comparative study of the latent variables in selected developing countries in sub-Saharan Africa would be most appropriate.

\section{REFERENCES}

Agba, A.M.O. (2007). External factors in industrial crisis: a study of higher institutions in Cross River and Akwa Ibom States,Nigeria (Ph.D. Thesis). Faculty of Social Science, University of Calabar, Nigeria.

Adetoyin, Y.T. (2012). Effect of pay on organisational effectiveness. Ibadan: Idowu Press. 
Almarshad, S.O. (2015). A Measurement Scale for Evaluating Quality of Work Life: Conceptualization and Empirical Validation. Trends in Applied Sciences Research, 10(3), 143-156. http://dx.doi.org/10.3923/tasr.2015.143.156

Armstrong, M. (2014). Armstrong's handbook of human resource management practice (13th edition). UK: Kogan Page Ltd.

Bartlett, M.S. (1954). A note on the multiplying factors for various chi square approximations. Journal of the Royal Statistical Society, 16(Series B), 296-298.

Blau, P. (1964). Exchange and power in social life. New York: John Wiley and Son.

Bowley, A.L. (1926). Measurements of precision attained in sampling. Bulletin of the International Statistical Institute, 2, 1-62

Clark, S.C. (2000). Work/family border theory: a new theory of work/family balance. Human Relations, 53, 747-770.

Cook, K.S., \& Rice, E. (2003). Social exchange theory. In J. Delamater (Ed.), Handbook of Social Psychology (pp. 53-76). New York: Kluwer Academic/Plenum Publishers.

Coyle-Shapiro, J.A.M., \& Parzefall, M. (2008). Psychological contracts. In C.L. Cooper \& B. Julian (Eds.), The SAGE handbook of organisational behaviour (pp. 17-34). London, UK: SAGE Publications.

Das, S.H. \& Gope, A.K. (2013). Employees' perception on quality of work life (QWL) in Sugar Mills of U.P.: a comparative study based on working environment factor. Pacific Business Review International, 6(4), 76-84.

David, L., Brazil, K., Krueger, P., Lohfield, L., \& Tjam, E. (2001). Extrinsic and intrinsic determinants of quality of work life. International Journal of Health Care Quality Assurance Incorporating Leadership In Health Services, 14(3), 9-15. http://dx.doi.org/10.1108/13660750110391539

Delbecq, A.L., Van de Ven, A.H., \& Gustafson, D.H. (1975). Group techniques for program planning. Glenview, IL: Scott, Foresman \& Co.

Diener, E., Emmons, R.A., Larsen, R.J., \& Griffin, S. (2010). The satisfaction with life scale. Journal of Personality Assessment, 49(1), 71-75. http://dx.doi.org/10.1207/s15327752jpa4901_13

Easton, S., \& Van Laar, D. (2013). Evaluation of outcomes and quality of working life in the coaching setting. The Coaching Psychologist, 9(2), 71-77.

Emerson, R.M. (1976). Social exchange theory. Annual Review of Sociology, 2(1), 335-362.

Emerson, R.M. (1987). Toward a theory of value in social exchange. In K.S. Cook (Ed.), Social exchange theory (pp. 11-58). Newbury Park, CA: Sage.

Field, A. (2009). Discovering statistics using SPSS (3rd edition). London, UK: SAGE Publications Ltd.

Gardner, S.D., Lepak, D.P., \& Bartol, K.M. (2003). Virtual HR: the impact of information technology on the human resource professional. Journal of Vocational Behaviour, 63, 157-179. http://dx.doi.org/10.1016/S0001-8791(03)00039-3

Gauri, S.R. (2015). Organisational justice and quality of working life: a road that leads to a virtuous organisation. Journal of Social Service Research, 41(2), 269-294. http://dx.doi.org/10.1080/01488376.2014.987942

Gerhart, B., \& Milkovich, G.T. (1991). Employee compensation: research and practice (CAHRS Working Paper \#91-35). Ithaca, NY: Cornell University, School of Industrial and Labor Relations, Center for Advanced Human Resource Studies. Retrieved on April 22, 2015 from www.http://digitalcommons.ilr.cornell.edu/cahrswp/365

Hackman, J.R., \& Oldham, G.R. (1976). Motivation through the design of work: test of a theory. Organizational Behavior and Human Performance, 16, 250-279. https://doi.org/10.1016/00305073(76)90016-7 
Hair, J., Black, W., Babin, B., \& Anderson, R. (2010). Multivariate data analysis (7th edition). Upper Saddle River, NJ: Pearson Prentice Hall.

Haitovsky, Y. (1969). Multicollinearity in regression analysis: a comment. Review of Economics and Statistics, 51(4), 486-489.

Hassan, F., Keeney, S., \& McKenna, H. (2000). Research guidelines for the Delphi survey technique. Journal of Advanced Nursing, 32(4), 1008-1015.

Homans, G.C. (1961). Social behaviour and its elementary forms. New York: Harcourt, Brace and World.

Horn, J.L. (1965). A rationale and test for the number of factors in factor analysis. Psychometrika, 30, 179-195.

Hossain, M. (2013). Perceptual factors in quality of working life of the garments workers in Bangladesh. Journal of Business Studies, 34(2), 1-12.

Hsu, C.C., \& Sandford, B.A. (2007). The Delphi technique: making sense of consensus. Practical Assessment, Research and Evaluation, 12(10), 1-8.

Hunker, I.K. (2014). Quality of work life in the hospitality industry: the contingent workers' perspective (Master Thesis). Copenhagen Business School.

Imafidon, A. (2013). Challenges of e-banking and payment system in Nigeria. Journal of Chartered Institute of Bankers of Nigeria, 7(4), 76-84.

Inyang, B.J., \& Akpana, M.A. (2012). Personnel management practice in Nigeria. Calabar: Merb Business.

Iverson, R.D., \& Maguire, C. (2000). The relationship between job and life satisfaction: evidence from a remote mining community. Human Relations, 53(6), 807-839. http://dx.doi.org/10.1177/0018726700536003

Kaiser, H.F. (1970). A second generation Little Jiffy. Psychometrika, 35, 401-415.

Kaiser, H.F. (1974). An index of factorial simplicity. Psychometrika, 39, 31-36.

Kwahar, N. (2016). Effect of quality of work life on Organisational performance in the Nigerian hotel sector (Ph.D. Thesis). Department of Business Management, Faculty of Management Sciences, Benue State University, Makurdi, Nigeria.

Levine, M.F., Taylor, J. C., \& Davis, L.E. (1984). Defining Quality of Working Life. Human Relations, 37(1), 81-104. http://dx.doi.org/0018-7267/84/0100-0081\$03.50/1

Levine, M.G. (1983). Self developed QWL measures. Journal of Occupational Behaviour, 4(1), 35.

Levitt, S.D., \& List, J.A. (2011). Was there really a Hawthorne Effect at the Hawthorne plant? An analysis of the original illumination experiments. American Economic Journal: Applied Economics, 3(1), 224-238. http://dx.doi.org/10.1257/app.3.1.224

Linstone, H.A. (1978). The Delphi technique. In J. Fowlers (Ed.),Handbook of Futures Research (pp. 273-300). Westport, CT: Greenwood Press.

March, J.G., \& Simon, H.A. (1993). Organisations (2nd edition). UK: Wiley-Blackwell.

Matsunaga, M. (2010). How to factor-analyze your data right: do's, don't's and how-to. International Journal of Psychological Research, 3(1), 97-110. http://dx.doi.org/10.21500/20112084.854

Merenda, P.F. (1997). A guide to the proper use of factor analysis in the conduct and reporting of research: pitfalls to avoid. Measurement and Evaluation in Counseling and Development, 30(3), 156-164.

Mirvis, P.H., \& Lawler, E.E. (1984). Accounting for the quality of work life. Journal of Occupational Behaviour, 5, 197-212. http://dx.doi.org/10.1002/job.4030050304

Mohamad, M., \& Mohamed, W.N. (2012). A model of quality of work life, life satisfaction and service quality. Asian Journal of Business Research, 2(2), 38-51. http://dx.doi.org/10.14707/ajbr.120009.

Mohammad, R.F.P., Sayyed, M.A., \& Reza, A. (2013). Effect of quality of work life on Organisational commitment by SEM (case study: OICO Company). International Journal of Academic Research in Business and Social Sciences, 3(10), 135-144. http://dx.doi.org/10.6007/IJARBSS/v3-i10/285 
Namasivayam, K., Miao, L., \& Zhao, X. (2007). An investigation of the relationships between compensation practices and firm performance in the US hotel industry. International Journal of Hospitality Management, 26(3), 574-587.

Naude, R., Kruger, S., \& Saayman, M. (2015). The effect of casino employees' demographic variables on QWL domains. African Journal of Hospitality, Tourism and Leisure, 4(2), 1-30.

Nickson, M. (2009). Human resource management for the hospitality and tourism industries. USA: Elsevier Ltd.

Nunnally, J.C. (1978). Psychometric theory. New York: McGraw-Hill.

Nwadukwe, U.O. (2012). Healthy environment Management and effectiveness of hotel industries in Anambra State of Nigeria. Anambara: Gozie Publisher Ltd.

Peterson, R.A. (2000). A meta-analysis of variance accounted for and factor loadings in exploratory factor analysis. Marketing Letters, 11(3), 261-275.

Psychogio, A.G. (2005). Towards a contingency approach to promising business management paradigms: the case of total quality management. Journal of Business and Society, 18(1/2), 120-134.

Pulakos, E.D. (2009). Performance management: a new approach for driving business results. London, UK: John Wiley \& Sons.

Rethinam, G.S., \& Ismail, M. (2008). Constructs of quality of work life: a perspective of information and technology professionals. European Journal of Social Sciences, 7(1), 58-70. http://dx.doi.org/10.12691/education-4-20-3.

Rousseau, D.M. (1995). Psychological contracts in Organisations: understanding written and unwritten agreements. Thousand Oaks, CA: Saga.

Selvan, V.T. (2015). Study on role of technology in human resource management. International Journal of Applied Research, 1(7), 472-475.

Shengbin, H., \& Bo, Y. (2011). The impact of technology selection on innovation success and organisational performance. iBusiness, 3, 366-371. http://dx.doi.org/10.4236/ib.2011.34049

Skulmoski, G.J., Hartman, F.T., \& Krahn, J. (2007). The Delphi method for graduate research. Journal of Information Technology Education, 6, 1-21.

Sojka, L. (2014). Specification of the quality of work life characteristics in the Slovak economic environment. Sociologia, 46(3) 283-299.

Stevens, J. (2002). Applied multivariate statistics for the social sciences (4th edition). Hillsdale, NJ: Erlbaum.

Swamy, D.R., Nanjundeswaraswamy, T.S., \& Rashmi, S. (2015). Quality of work life: scale development and validation. International Journal of Caring Sciences, 8(2), 281-300.

Tabachnik, B.G., \& Fidell, L.S. (2007). Using multivariate statistics (5th edition). USA: Pearson Education Inc.

Yamane, T. (1967). Statistics: An Introductory Analysis (2nd edition). New York: Harper and Row.

Thangaratinam, S., \& Redman, C.W.E. (2005). The Delphi technique. The Obstetrician and Gynaecologist, 7, 120-125. http://dx.doi.org/10.1576/toag.7.2.120.29071

Thompson, E.R., \& Phua, F.T. (2012). A brief index of affective job satisfaction. Group and Organization Management, 37(3), 275-307. http://dx.doi.org/10.1177/1059601111434201

Thurstone, L.L. (1947). Multiple factor analysis. Chicago: University of Chicago Press.

Tinsley, H.E.A., \& Tinsley, D.J. (1987). Uses of factor analysis in counselling psychology research. Journal of Counseling Psychology, 34(4), 414-424.

Van Laar, D., Edwards, J.A., \& Easton, S. (2007). The work-related quality of life scale for healthcare workers. Journal of Advanced Nursing, 60(3), 325-333. http://dx.doi.org/10.111/j.1365-2648.2007.04409.x 
Walton, R.E. (1974). Quality of work life indicators: prospects and problems. In A.H. Portigal (Ed.), Measuring the quality of working life. A symposium on social indicators of working life. Ottawa, 19-20 March.

Wyatt, T.A., \& Wah, C.Y. (2001). Perceptions of QWL: a study of Singaporean employees development. Research and Practice in Human Resource Management, 9(2), 59-76.

Yong, G.A., \& Pearce, S. (2013). A beginner's guide to factor analysis: focusing on exploratory factor analysis. Tutorials in Quantitative Methods for Psychology, 9(2), 79-94.

\section{Appendix}

Quality of Work Life Indicators

\begin{tabular}{|c|c|c|}
\hline Adequate remuneration. & Leadership training programme. & Continuous review of pay reviews. \\
\hline Objectives of training programme. & Performance based remuneration. & Fair and unbiased promotion system. \\
\hline $\begin{array}{l}\text { Availability of health care and medical } \\
\text { facilities. }\end{array}$ & Reward for good work. & Safety measures/policies at work. \\
\hline $\begin{array}{l}\text { Employees' own style and pace of } \\
\text { work. }\end{array}$ & No time for personal care. & Updated work environment. \\
\hline Reward management procedures. & Unusual and unique benefits. & $\begin{array}{l}\text { No minimal control at work by super- } \\
\text { visor when target met. }\end{array}$ \\
\hline Work freedom. & Grooming new leaders. & $\begin{array}{l}\text { Corporate culture supports work-life } \\
\text { balance. }\end{array}$ \\
\hline Recompense. & Written and explicit no-layoff policy. & Stability of employment. \\
\hline $\begin{array}{l}\text { Facilities at work support my family } \\
\text { life. }\end{array}$ & Pride in work/company. & $\begin{array}{l}\text { Inappropriate fair job rotation pro- } \\
\text { gramme. }\end{array}$ \\
\hline Regularity in updating talent. & $\begin{array}{l}\text { Work position and prospects of career } \\
\text { development. }\end{array}$ & $\begin{array}{l}\text { Communicating the need for better } \\
\text { health, safety practices. }\end{array}$ \\
\hline Satisfaction with present job. & $\begin{array}{l}\text { Management of stress in the organi- } \\
\text { sation. }\end{array}$ & $\begin{array}{l}\text { Flexibility in performing work respon- } \\
\text { sibility. }\end{array}$ \\
\hline Frequent leave granted to employees. & Wage balance. & Credibility, respect and fairness. \\
\hline $\begin{array}{l}\text { Camaraderie, friendliness and fruitful } \\
\text { relationship with co-workers and su- } \\
\text { pervisors. }\end{array}$ & Professionalism of career. & $\begin{array}{l}\text { Continuous risk assessment and safety } \\
\text { inspections in the organisation. }\end{array}$ \\
\hline $\begin{array}{l}\text { Suitability of work hours/patterns to } \\
\text { suit personal preference. }\end{array}$ & Productivity at work. & $\begin{array}{l}\text { Opportunities for time off work with } \\
\text { family and friends. }\end{array}$ \\
\hline $\begin{array}{l}\text { Waste and pollution policies at work } \\
\text { environment. }\end{array}$ & $\begin{array}{l}\text { Opportunities for management/oper- } \\
\text { ational decision-making. }\end{array}$ & $\begin{array}{l}\text { Supportive management and stimulat- } \\
\text { ing job and career opportunities. }\end{array}$ \\
\hline Satisfaction with career opportunities. & Availability of convenience facilities. & No organisation-wide bonus scheme. \\
\hline Fair financial incentive plan. & $\begin{array}{l}\text { Non-availability of home-life balance } \\
\text { programme. }\end{array}$ & Attractiveness of present career. \\
\hline $\begin{array}{l}\text { Training programmes aimed at im- } \\
\text { proving interpersonal etc. skills in us- } \\
\text { age of modern tools and equipment. }\end{array}$ & $\begin{array}{l}\text { Frequency and sufficiency of relevant } \\
\text { and targeted training programme. }\end{array}$ & $\begin{array}{l}\text { Appropriately implemented allow- } \\
\text { ances and benefits (location allow- } \\
\text { ances, overtime, shift allowance). }\end{array}$ \\
\hline $\begin{array}{l}\text { Timely payment of salaries and allow- } \\
\text { ance. }\end{array}$ & Adequate employee benefits. & $\begin{array}{l}\text { Equal opportunities for women em- } \\
\text { ployees. }\end{array}$ \\
\hline $\begin{array}{l}\text { Above average industry median re- } \\
\text { muneration. }\end{array}$ & $\begin{array}{l}\text { Strict layoff policies or strict imple- } \\
\text { mentation of same }\end{array}$ & Team-based pay schemes. \\
\hline $\begin{array}{l}\text { Training programmes focus on em- } \\
\text { ployee requirements to ensure filling } \\
\text { vacancies in-house. }\end{array}$ & Fair remuneration. & $\begin{array}{l}\text { Communicating of policies to employ- } \\
\text { ees. }\end{array}$ \\
\hline $\begin{array}{l}\text { Adequate and comprehensive grade } \\
\text { and pay structures. }\end{array}$ & $\begin{array}{l}\text { Non-participation in development of } \\
\text { remuneration system. }\end{array}$ & Salubrious work environment. \\
\hline
\end{tabular}




\section{Authors}

The contribution of co-authors is equal and can be expressed as $50 \%$ each of the authors: N. Kwahar prepared the literature review, while A. S. Iyortsuun prepared the statistical calculations.

\section{Nguwasen Kwahar}

BSc Business Administration (Ahmadu Bello University, Zaria, Kaduna State, Nigeria); MBA Management (Benue State University, Makurdi, Nigeria); MSc Industrial Psychology (Benue State University, Makurdi, Nigeria); PhD in Management (Benue State University Makurdi, Nigeria). Her research interests include organisational behaviour and human resource management.

Correspondence to: Nguwasen Kwahar, PhD, University of Agriculture, College of Management Sciences, Nigeria, e-mail: ngu.kwahar@gmail.com

\section{Akuraun Shadrach lyortsuun}

Lecturer in the Department of Business Administration, Federal University, Wukari with current research interest in business incubation and small business firms.

Correspondence to: Akuraun Shadrach lyortsuun, MSc., Department of Business Administration Faculty of Humanities, Management \& Social Sciences, Federal University, Wukari, Nigeria, e-mail: shadrach@fuwukari.edu.gn

\section{Acknowledgements and Financial Disclosure}

The authors wish to appreciate the University of Agriculture, Makurdi, Benue State, Nigeria and the Federal University, Wukari, Taraba State, Nigeria for their financial support during the period of this research.

We wish to acknowledge the contribution by Prof Ayatse, Fidelis, Dean, College of Management Sciences, Dr. Nongo, Saasongo, Dr Agburu, John. and Dr. Ver Bernard, all of the Benue State University, Makurdi, Nigeria for their inputs during the development of this article. Our acknowledgement also goes to the National Institute for Hospitality and Tourism for insightful contribution by providing relevant information and data that were used in carrying out this research work. Their contributions are highly appreciated.

\section{Copyright and License}

This article is published under the terms of the Creative Commons

Attribution - NoDerivs (CC BY-ND 4.0) License

http://creativecommons.org/licenses/by-nd/4.0/

Published by the Centre for Strategic and International Entrepreneurship - Krakow, Poland 